\title{
ポリエチレンテレフタレートの低温における誘電緩和挙動に 対する結晶化度の影響*
}

\author{
山登正文*1 ・巽 富美男*2 $・$ 伊藤 栄子*1
}

（受付 1992 年 9 月 11 日・蕃査終了 1992 年 12 月 7 日）

\begin{abstract}
旨 ポリエチレンテレフタレートにおける $\beta$ 分散の緩和時間，緵和強度などに及ばす結晶化の影慗を誘電測 定加考察することを目的とした. 今まで, 周波数分散における吸収極大周波数 $f_{\max }$ は結晶化の影整をほとんど受 けないとされてきたが, 本実験においては結晶化度か增加するにつれて高周波数側にシフトするのか観察された。 すなわち，結晶化度の增加により $\beta$ 分散の䌊和時間か短くなることを見いだした，また，緩和强度は非晶の量に比 判しており、結晶化度の增加とともに娍少した。活性化エネルギーには結晶化度传存性はほとんど見られなかっ た.
\end{abstract}

\section{1 粕言}

重要なエンジニアリングプラスチックの一つであるポ リエチレンテレフタレート (PET) の低温における誘電 緩和, すなわち $\beta$ 分散について, 今までに多くの研究が なされてきている. PETのような芳香族ポリエステル は，㑡鎖を持たず極性基が主鎖中に含まれているので， 低温の分散である $\beta$ 分散も主鎖のセグメント運動であ る $a$ 分散之同様に, 主鎖の運動性を直接反映していると 考えられる.これまで PETの $\beta$ 分散については, 誘電緩 和 ${ }^{(1)}$, 力学的測定 ${ }^{(3)-6)}$, 広幅核磁気共鳴 ${ }^{7)}$ などの方法を 用いて研究がなされてきている.これら実験から求めら れた $\beta$ 分散の見かけの活性化エネルギーは12〜16 kcal/ $\mathrm{mol}$ 程度の小さな値であり, また $\beta$ 分散のアレニウスプ ロットは良い直線性を示すことからも， $\beta$ 分散の運動単 位は小さいと考えられ，具体的には主鎖中の極性基のみ の運動とする考え方が支配的であった。. 今までに， $\beta$ 分 散に寄与する分子鎖運動として次に述べるいくつかの機 構が提唱されてきている.

（1）分子鎖末端のヒドロキシル基の運動 ${ }^{1}$,

(2) COO 双極子を含んだ主鎖の局所運動), 7),

(3) 周囲の粘性抵抗によってタンプされた主鎖の回 転振動 (torsional vibration) ${ }^{8), 9)}$ などである.

$\beta$ 分散が上記 (1) に示した分子鎖末端のヒドロキシル 基の運動であるならば, $\beta$ 分散の楥和強度は分子量依存

* 本報を「ポリエチレンテレフタレートの低温における誘電 楥和举動に成する研究 第 1 報」とする.

*1 東京都立大学工学部工業化学科（192-03 東京都八王子市 南大沢 1-1)

*2 出光興産株式会社（-299-02 千葉県袖ヶ浦市上泉 1280）
性を示すはずである. しかし，いろいろな重合度の PET の緩和強度を測定したところ, 緩和強度には分子量依存 性が認められなかった ${ }^{10}$.

$\beta$ 分散の周波数分散スペクトルの形はブロードで非対 称であるため ${ }^{2}, \beta$ 分散のスペクトルはグリコール残基 のトランス, ゴーシュの二つのコンホメーションより成 り立っているとする(2) のような考え方がある4).6). 一 方，PET を一軸に延伸し分子鎖を一方向に配向させた試 料ではトランスーコンホメーションの量が增加すること が報告されている゙1). $\beta$ 分散がトランスとゴーシュの二 つのコンホメーションより成り立っているならば, トラ ンス量の変化に伴い $\beta$ 分散のスペクトルが变化するは ずである. しかし, 延伸により吸収最大の周波数は変化 するが $\beta$ 分散のスペクトルの形はほとんど変化しな (12). したがって, $\beta$ 分散はいくつかの成分から成り 立っているのではなく, $\mathrm{COO}$ 双極子を含んだ主鎖の回 転振動が周囲の粘性抵抗によってダンプされた運動とし て取り扱う方がよいと考えられる8)，このように PET の $\beta$ 分散がある程度の長さの範囲に渡って分子銷が相 関を持って運動するとするならば，結晶化により影響を 受けることが考えられる. しかし,これまでPETの $\beta$ 分 散は主鎖中の極性基を含むかなり短い範囲の運動である とされている. また, 結晶化の影響が観察されたのは, 非晶領域の量の減少による緩和強度の減少のみであ $\eta^{22,3)}$, 分子鎖運動の速さの目安である周波数分散にお ける吸収極大の周波数 $f_{\max }$ については結晶化の影敏がほ とんどないとされている.

本研究はPET の $\beta$ 分散に与える結晶化度の影響を楥 和強度, $f_{\max }$, 活性化エネルギー, および緩和パラメー ター（Havriliak-Negami 式におけるパラメーター）から 


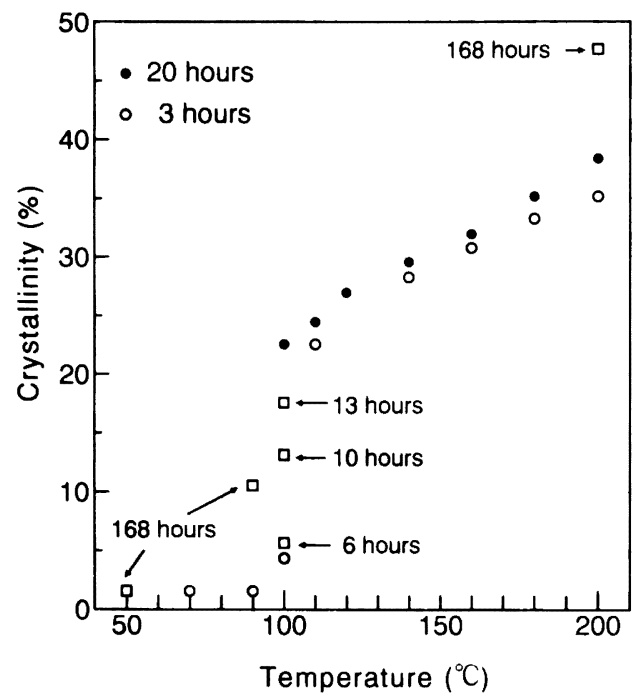

Fig. 1. Crystallinity of the annealed samples.

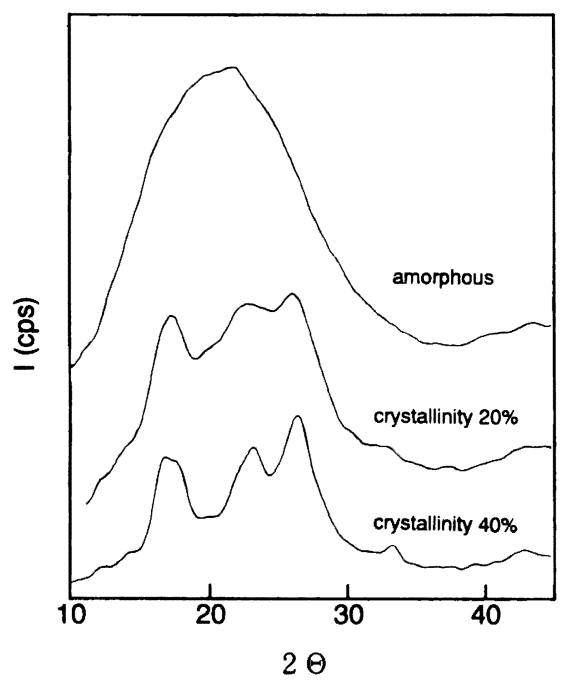

Fig. 2. X-Ray difraction diagrams of the annealed samples.

考察することを目的とした。

\section{2 実験}

\section{1 試料}

非晶性試料として帝人(株)製未延伸のポリエチレンテ レフタレート(PET)（厚さ $40 \mu \mathrm{m}$ ) フィルムを用いた.

このフィルムが非晶であることを $\mathrm{X}$ 線および密度測定 より確認した。

\section{2 結晶化}

非晶性 PET フィルムを $50 \sim 200^{\circ} \mathrm{C}$ の範囲で所定の温
度に設定した空気恒温槽中で 3〜168 時間の間で熱処理 時間を変え熱処理をし，いろいろな結晶化度の試料を得 た.

\section{3 密度测定}

n-ヘプタンー四塩化炭素系密度勾配管を用いて密度を $22^{\circ} \mathrm{C}$ で測定し，二相構造を仮定し結晶化度を算出した。 PET の非晶相の密度は $1.336 \mathrm{~g} / \mathrm{cm}^{3}{ }^{13)}$, 結晶相の密度と して $1.495 \mathrm{~g} / \mathrm{cm}^{3}{ }^{(3)}$ を用いた。

\section{4 広角 X 線回折}

マックサイエンス社製 MXP18X 線回折装置を用い X 線回折を測定した. 出力は $40 \mathrm{KV}, 200 \mathrm{~mA}$ で 5 45 の範 井の角度で回折パターンを得た。

\section{5 誘電測定}

$-60 \sim-20^{\circ} \mathrm{C}$ の温度範囲で，各試料の誘電率 $\varepsilon^{\prime}$ 之誘 電損失 $\varepsilon^{\prime \prime}$ を周波数の関数として測定した。周波数範囲 は $10 \mathrm{~m} \sim 10 \mathrm{MHz}$ とした，測定装置はYHP4194A イン ピーダンスアナライザーおよび NF 回路設計プロック社 製 S-5720 周波数応答分析器を用いた。 得られた周波数 分散スペクトルから $\beta$ 分散の誘電緩和パラメーターを

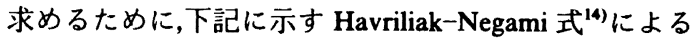
最適化を行った。最適化には非線形最小二乗法を用い た。

$\varepsilon^{*}(\omega)-\varepsilon_{\infty}=\left(\varepsilon_{0}-\varepsilon_{\infty}\right) /\left[1+\left(j \omega \tau_{0}\right)^{1-a}\right]^{\beta} \quad(0<\alpha, \beta \leqq 1)$

$\varepsilon^{*}(\omega)$ は角周波数 $\omega$ における複素誘電率, $\tau_{0}$ は Havriliak-Negami の式における特性緩和時間である. $\varepsilon_{0}$ と $\varepsilon_{\infty}$ は平衡時之瞬時における誘電率を表し, 緩和強度 $\Delta \varepsilon$ は $\Delta \varepsilon=\varepsilon_{0}-\varepsilon_{\infty}$ で表される. $\varepsilon_{0}$ と $\varepsilon_{\infty}$ は複素平面プロット において周波数零および無限大に外挿した時の横軸の交 点より求められる.

\section{3 実験結果および考察}

Fig. 1 に各温度における熱処理による結晶化度の変化 を示す. $100^{\circ} \mathrm{C}$ の熱処理では処理時間とともに結晶化度 か增加することが分かった. $100^{\circ} \mathrm{C}$ 以上での熱処理では, 3 時間之 20 時間の熱処理時間の差はあまり大きくなく, 温度依存性の方が顕著であり, 熱処理温度の上昇ととも に結晶化度か增加している。

Fig. 2 に非晶, 結晶化度 $20 \%$ と $40 \%$ のそれぞれの広 角 $\mathrm{X}$ 線回折パターンを示した. $100^{\circ} \mathrm{C}$ で 20 時間の熱処 理により得られた試料は密度測定からは結晶化度 $20 \%$ との結果が得られているが，X 線的に分子鎖が十分に規 則正しく配列していないことを示している.

誘電損失曲線の温度依存性は各試料とも同じ挙動を示 した. 例として Fig. 3, 4 に非晶,結晶化度 $40 \%$ の誘電損 失曲線の温度変化を示した. すべての試料においてブ ロードで高周波数側がなだらかな PET に特有な $\beta$ 分散 が観察された，損失曲線は温度が低下するとともに $\varepsilon^{\prime \prime}$ の極大値 $\varepsilon_{\max }^{\prime \prime}$ は減少し, $\varepsilon^{\prime \prime}$ が極大を示す周波数 $f_{\max }$ は低 
ポリエチレンテレフタレートの低温における誘電緩和挙動に対する結晶化度の影響

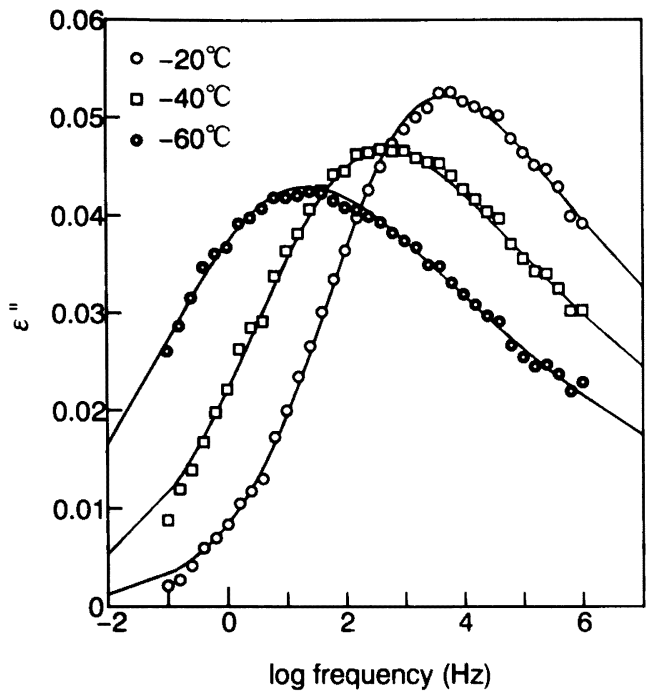

Fig. 3. Dielectric loss plotted versus log frequency at $-20^{\circ} \mathrm{C},-40^{\circ} \mathrm{C}$, and $-60^{\circ} \mathrm{C}$ for the amorphous sample.

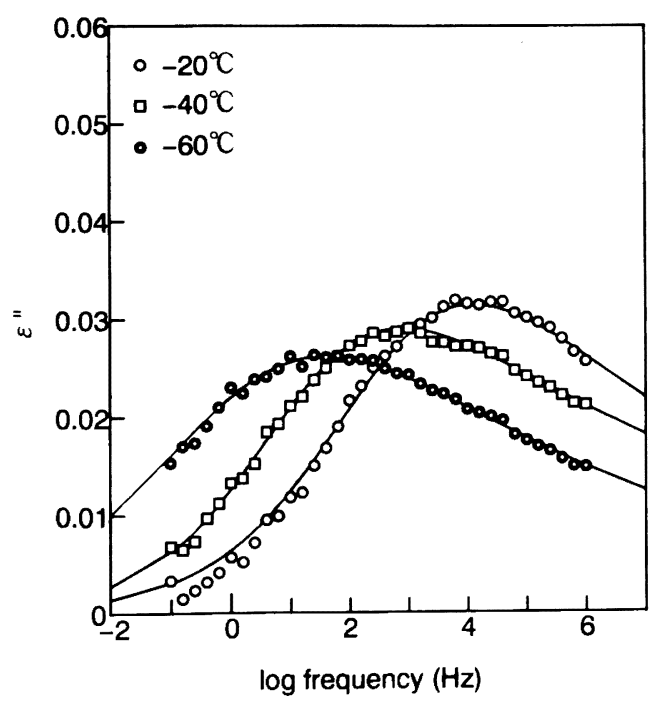

Fig. 4. Dielectric loss plotted versus log frequency at $-20^{\circ} \mathrm{C},-40^{\circ} \mathrm{C}$, and $-60^{\circ} \mathrm{C}$ for the annealed sample.

周波数側にシフトしていく．結晶化度の違いによる誘電 損失曲線の变化を Fig. 5 に示した．結晶化度の增加に伴 い誘電損失曲線はプロードになり $\varepsilon_{\max }^{\prime \prime}$ は減少し， $f_{\max }$ は 高周波数側へシフトしていく. Fig. 6 に $f_{\text {max }}$ に及ぼす結 晶化度の影每を示した。 $f_{\max }$ の対数と結晶化度とは良い 直線関係にあることが分かる。. $f_{\max }$ と緩和時間とは逆数 の関係にあるから, Fig. 6 の結果はPET の $\beta$ 分散は結晶

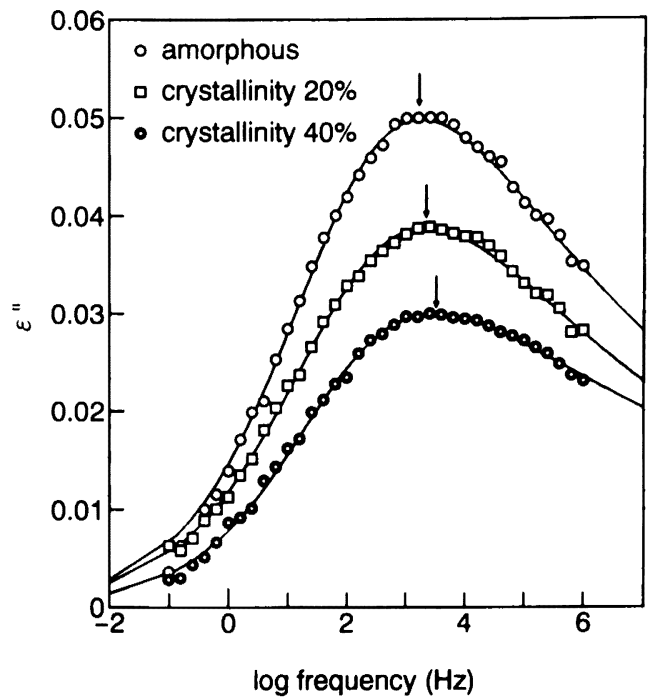

Fig. 5. Change of the dielectric loss at $-30^{\circ} \mathrm{C}$ by crystallization $\left(\downarrow, f_{\max }\right)$.

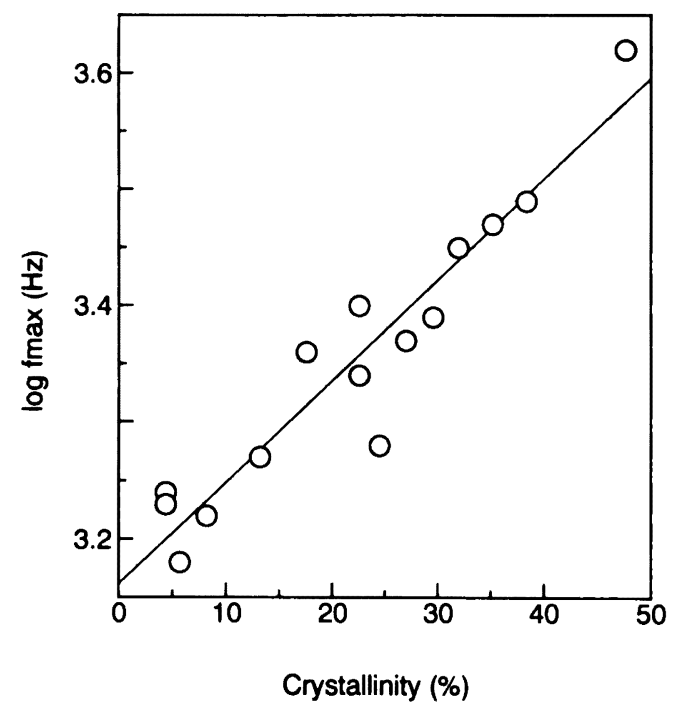

Fig. 6. Crystallinity dependence of the $\log f_{\max }$ at $-30^{\circ} \mathrm{C}$.

化の影響を受けて，結晶化度の增加に伴い緩和時間が短 くなることを示している.

今まで PET の $\beta$ 分散についてなされている報告は $f_{\max }$ に結晶化の影響がないとされている，その理由は主 に以下に述べる二つの理由によるものと考えられる.

(1) 測定機器の性能が良くなり, 測定周波数の領域 が広くなるとともに，測定点が非常に多くなったことな 


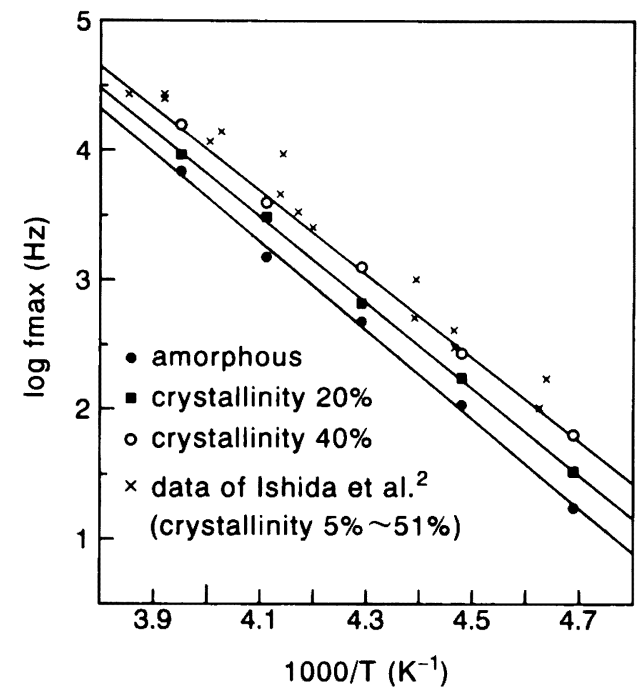

Fig. 7. Temperature dependence of $\log f_{\max }$ (Arrhenius plot) for annealed samples.

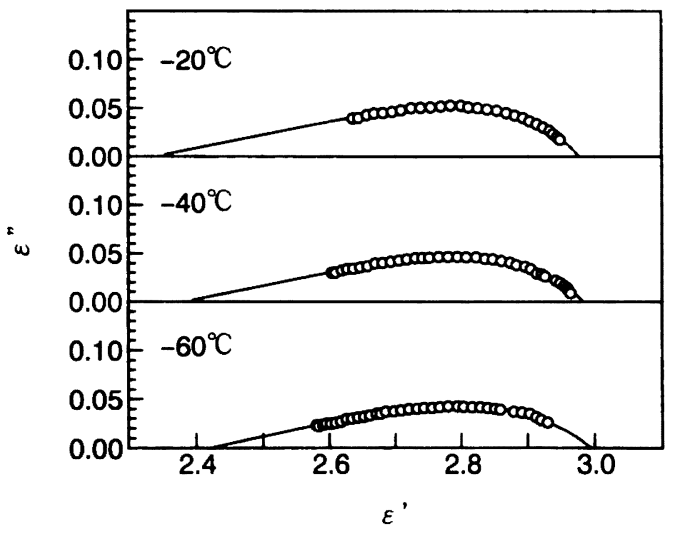

Fig. 8. Cole-cole plots of the amorphous sample at $-20^{\circ} \mathrm{C},-40^{\circ} \mathrm{C}$, and $-60^{\circ} \mathrm{C}$.

どで， $f_{\max }$ の位置を精度良く求められることができるよ うになった。

(2) 試料の乾燥の問題がある. 水の誘電率は大きい. それに比べて PET の $\beta$ 分散の $\varepsilon^{\prime \prime}$ は値が小さいので, 試 料の乾燥が不十分であると水の影響を受け, 結晶化によ る $f_{\max }$ の変化が分からなくなる.

$f_{\text {max }}$ が結晶化度の增加とともに高周波数側にいく理由 として，次のようなことが考えられる．PET の核生成速 度之結晶成長速度の温度依存性 ${ }^{15}$ はガラス転移温度以上 $190^{\circ} \mathrm{C}$ までは核生成速度が大きく, $190^{\circ} \mathrm{C}$ 以上からは結

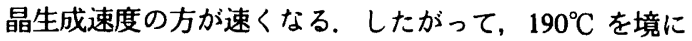
この温度より上と下の温度での結晶化では非晶の状態が

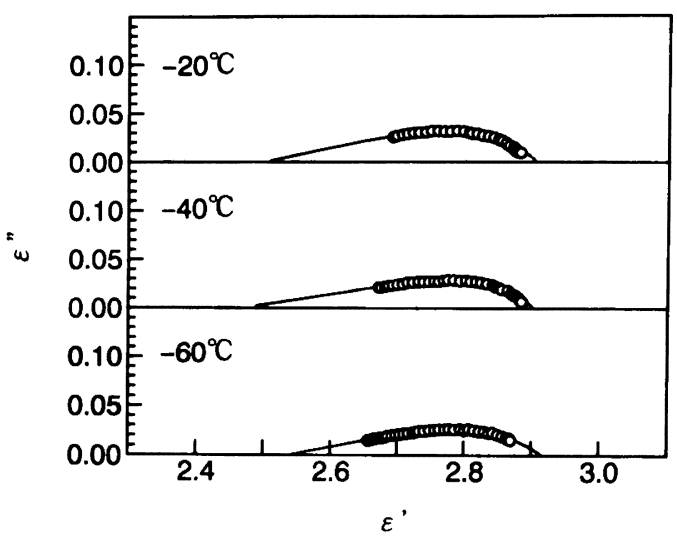

Fig. 9. Cole-cole plots of the annealed sample (crystallinity $40 \%$ ) at $-20^{\circ} \mathrm{C},-40^{\circ} \mathrm{C}$, and $-60^{\circ} \mathrm{C}$.

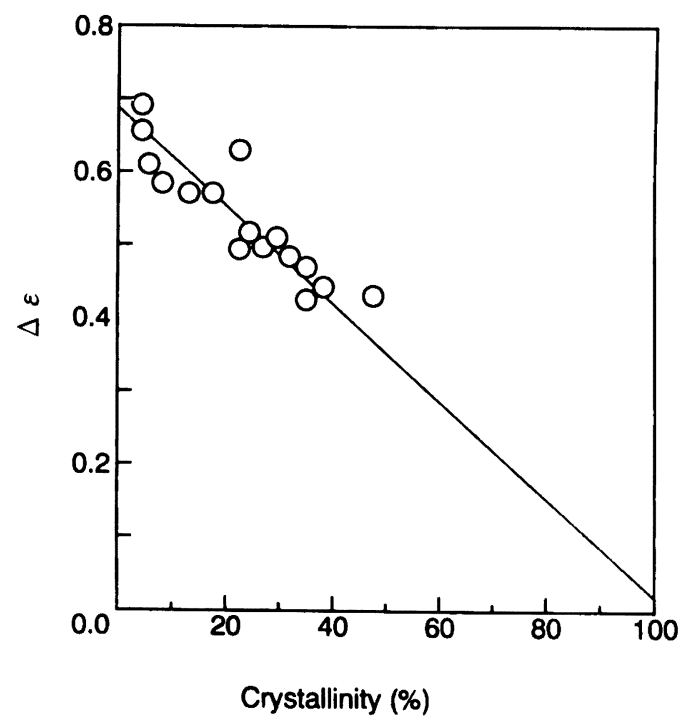

Fig. 10. Crystallinity dependence of the dielectric strength $(\Delta \varepsilon)$ at $-30^{\circ} \mathrm{C}$.

異なると思われる，すなわち， $190^{\circ} \mathrm{C}$ 以下での結晶化で は核のできる速度が速いため非晶領域の分子鎖は核と 核，または核と結晶とに挟まれ張力がかかっている状態 と考えられる. 今， $f_{\max }$ が分子内復元力之分子間の摩擦

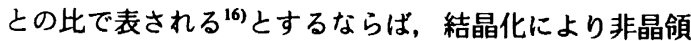
域の分子鎖に張力がかかり，分子鎖内の据じれに対する 復元力が增加したと考えられるが，正確なことは現在不 明であり今後の研究に期待したい。

次に $f_{\max }$ の温度依存性を考察してみる．各試料とも同 じ温度依存性を示したので, 例として非晶性試料と結晶 化度 $20 \%$, 結晶化度 $40 \%$ の試料の $f_{\max }$ の温度依存性, すなわちアレニウスプロットを Fig. 7 に示した，而試料 
ポリエチレンテレフタレートの低温における誘電緩和挙動に対する結晶化度の影響

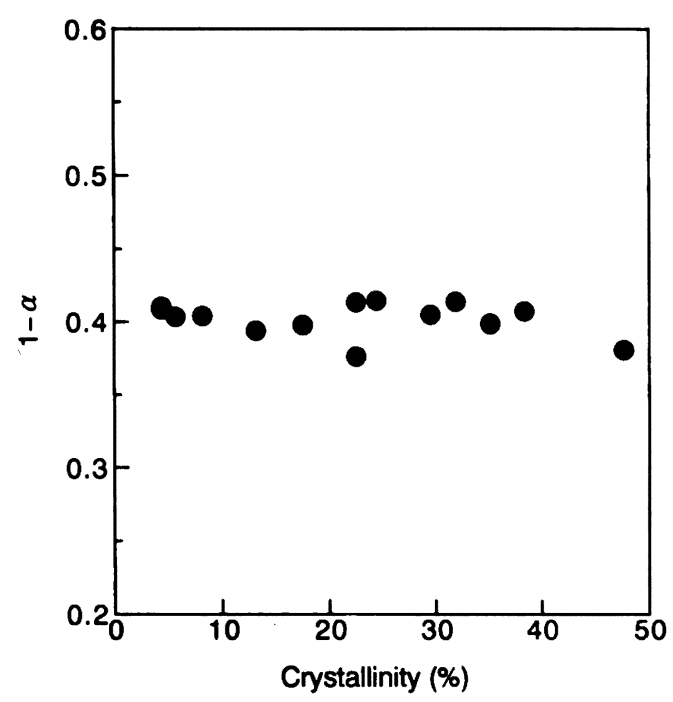

Fig. 11. Dependence of the alpha parameter at $-30^{\circ} \mathrm{C}$ on crystallinity.

ともに良い直線関係が得られ、これら直線の傾きはほと んどおなじで結晶化の影每は観察されなかった。 また， これら直線の傾きから求められた見かけの活性化エネル

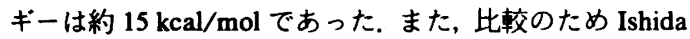
らのデータ $\left(\chi_{\mathrm{c}}=0.05 \sim 0.51\right)^{2)}$ のプロットを示してある. 非晶, 結晶化試料いずれも我々のデータよりも高周波数 側にあることが分かる。これは, 試料に吸着した水の影 整によるあのだと考えられる20).

Fig. 8, Fig. 9 に非晶性試料之結晶化度 $40 \%$ の試料の 複素平面プロットを示した。 図中の○印は実測値を，実 線は最適化の結果得られた曲線である. 最適化の結果得 られた曲線と実験結果とは非常に良く一致していること が分かる.この複素平面プロットから求められた緩和強 度 $\Delta \varepsilon$ への結晶化度の影響を Fig. 10 に示した。 $\Delta \varepsilon$ は結 晶化度か增加するにつれて, 結晶化度に比例して減少す ることが分かる．すなわち，結晶化度が $40 \%$ になると緩 和強度は非晶性試料の $3 / 5$ になる。 あし, 結晶化度 $100 \%$ の試料が得られるとすると, $\Delta \varepsilon$ の外括値はほとん ど零になる.これは主鎖セグメントの分子運動に起因す る主分散の緩和強度の結晶化度依存性 ${ }^{17)}$ (9) と全く同じ 挙動を示した。このように $\beta$ 分散も非晶領域の状態をよ く反映していると考えられる.

Fig. 11 に緩和時間の分布の幅を表すパラメーター $\alpha$ と結晶化度の関係を示した。この図からパラメーター $a$ の結晶化度依存性はほとんどないことが分かる。次に Fig. 12 に誘電損失曲線の非対称性を表すパラメーター に対するの結晶化度の影笠を示した．結晶化度に $\beta$ は大 きく依存しないが, 結晶化度が增すにつれてやや減少す

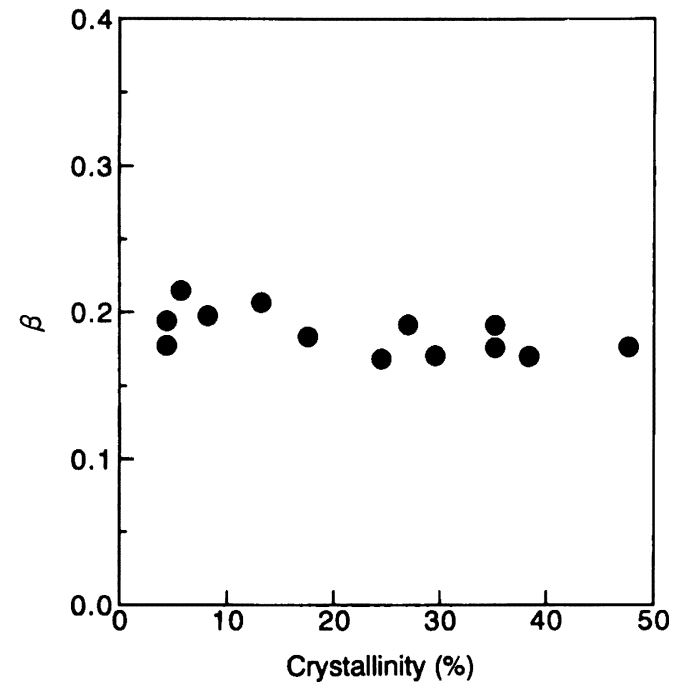

Fig. 12. Dependence of the beta parameter at $-30^{\circ} \mathrm{C}$ on crystallinity.

る傾向にある. すなわち，結晶化が進むにつれて損失曲 線の対称性が多少悪くなってくることを示している.

\section{4 結 論}

$50 \%$ の以下の結晶化度において, PET の $\beta$ 分散に与 える結晶化度の影響を誘電測定より考察したところ, 以 下のような結論を得た。

1) 周波数分散において緩和時間の目安となる吸収極 大の周波数 $f_{\max }$ は結晶化度か増加するにつれて, 高周波 数側にシフトする.すなわち，緩和時間が短くなる.

2) 緩和強度は非晶の量に比例して減少した。

3) Havriliak-Negami 式より求められた緩和パラ メーター $\alpha$ はほとんど結晶化により変化せず，緩和時間 の分布の広がりは結晶化度により変化しないことを示し た.

\section{文献}

1) W. Reddish, Trans. Farady Soc., 46, 459 (1950).

2) Y. Ishida, K. Yamafuji, H. Ito, and M. Takayanagi, Kolloid Z. -Z. Poym., 184, 97 (1962).

3) J. C. Coburn and R. H. Boyd, Macromolecules, 19, 2238 (1986).

4) K. H. Illers and R. H. Breuer, J. Colloid Sci., 18, 1 (1963).

5) V. Frosini and A. E. Woodward, J. Macromol. Sci. -Phys., B3, 91 (1969).

6) E. Sacher, J. Macromol. Sci. -Phys., B15, 257 (1978).

7) I. M. Ward, Trans. Farady Soc., 56, 648 (1960).

8) N. Saito, K. Okano, S. Iwayanagi, and T. Hideshima, "Solid State Physics", F. Seitz and D. Turnbull, Ed., Vol. 14, Academic Press, New York-London (1963), pp. 387 and 


\section{山登・巽・伊藤}

419.

9) K. Yamafuji, J. Phys. Soc. Jpn., 15, 2295 (1960).

10) E. Ito, Rep. Prog. Polym. Phys. Jpn., 26, 441 (1983).

11) 伊藤栄子, 畠山立子, 小山昭雄, 金綱久明, 岡島三郎, 工 業化学雑誌, 72, 154 (1969).

12) E. Ito, S. Okajima, H. Sasabe, and S. Saito, Kolloid Z.-Z. Polym., 251, 577 (1973).

13) S. Saito, Kolloid Z.-Z. Polym., 189, 116 (1963).

14) S. Havriliak and S. Negami, J. Polym. Sci., C, 14, 99 (1966).
15) L. B. Morgan, Phil. Trans. Roy. Soc. (London), Sec. A, 247, 23 (1952).

16）岡野光治, 理研報告, 40, 273 (1964).

17) 斎藤省吾, 中島達二, 材料試験, 8, 47 (1959).

18）斎藤省吾, 中島達二, 電試, 33, 180 (1959).

19）高柳素夫, 高分子, 10, 289 (1961).

20）巽 富美男，江連秀敏，伊藤栄子，高分子論文集，49,523 (1992).

\section{Effects of Crystallization on the $\beta$ Process of Poly(ethylene terephthalate)*}

Masafumi Yamato*1, Tomio TATUMI*2, and Eiko Ito*1

*Studies on Dielectric Relaxation Beharior of Poly(ethylene terephthalate) at the Low Temperature I.

${ }^{* 1}$ Department of Industrial Chemistry, Faculty of Technology, Tokyo Metropolitan University (1, Minami-ohsawa 1-chome, Hachioji, Tokyo, 192-03 Japan)

*2 Chemicals and Research Laboratories, Idemitu Kousan Co., Ltd. (Kami-izumi, Sodegaura, Chiba, 299-02 Japan)

The effects of crystallization on dielectric relaxation strength and relaxation time in the $\beta$ process were studied from dielectric measurements of poly (ethylene terephthalate). The frequency at a maximum absorption fmax increased with an increase in crystallinity, indicating that the relaxation time of the $\beta$ process decreases with an increase in crystallinity. The dielectric relaxation strength decreases with increasing crystallinity. The activation energy has a limited effect on crystallinity.

KEY WORDS Dielectric Relaxation Strength / Relaxation Time / $\beta$ Process / Crystallization /

Poly(ethylene terephthalate) /

(Received September 11, 1992: Accepted December 7, 1992)

[Kobunshi Ronbunshu, 50(3), 131-136 (1993)] 